\title{
Immunological Analysis of Treatment Interruption After Early Highly Active Antiretroviral Therapy
}

\author{
Ingrid M.M. Schellens, ${ }^{1}$ Katalin Pogany, ${ }^{2}$ Geertje H.A. Westerlaken,, José A.M. Borghans, \\ Frank Miedema, Irene G.M. van Valkengoed, ${ }^{3}$ Frank P. Kroon, ${ }^{4}$ Joep M.A. Lange, ${ }^{2}$ \\ Kees Brinkman, ${ }^{5}$ Jan M. Prins, ${ }^{2}$ and Debbie van Baarle ${ }^{1,6}$
}

\begin{abstract}
We longitudinally evaluated HIV-specific T-cell immunity after discontinuation of highly active antiretroviral therapy (HAART). After treatment interruption (TI), some individuals could maintain a low plasma viral load $(<15,000$ copies $/ \mathrm{mL})$, whereas others could not $(>50,000$ copies $/ \mathrm{mL})$. Before HAART was initiated, plasma viral load was similar. After TI, the numbers of $\mathrm{CD}^{+} \mathrm{T}$ cells increased more in individuals without viral control, whereas individuals maintaining a low viral load showed a more pronounced increase in HIV-specific $\mathrm{CD}^{+}$T-cell numbers. No differences were seen in the number or percentage of cytokine-producing HIV-1specific $\mathrm{CD}^{+}{ }^{+} \mathrm{T}$ cells, or in proliferative capacity of $\mathrm{T}$ cells. Four weeks after TI, the magnitude of the total HIV1-specific CD8 ${ }^{+}$T-cell response (IFN- $\gamma^{+}$and /or IL-2 ${ }^{+}$and $/$or $\mathrm{CD} 107 \mathrm{a}^{+}$) was significantly higher in individuals maintaining viral control. Degranulation contributed more to the overall CD8 ${ }^{+} \mathrm{T}$-cell response than cytokine production. Whether increased T-cell functionality is a cause or consequence of low viral load remains to be elucidated.
\end{abstract}

\section{Introduction}

$\mathbf{P}$ ERSISTENT ACTIVATION OF THE IMMUNE SYSTEM is one of the hallmarks of HIV-1 infection. This continuous state of hyperactivation, induced by ongoing viral replication, can be inhibited by effective treatment with highly active antiretroviral therapy (HAART). Treatment with HAART usually results in a decrease in HIV-1 viral load, which is associated with an increase in CD4 ${ }^{+}$T-cell numbers $(3,24,29)$, and a decrease in HIV-1-specific CD8 ${ }^{+}$T cells $(10,17,25,26)$. Furthermore, HIV-1-specific cellular immune responses were shown to decrease in individuals treated during chronic infection $(6,30)$. The decrease in T-cell activation levels that is typically observed during treatment (3) quickly rises again when treatment is interrupted (1). In treatment-naïve individuals, low levels of T-cell activation are associated with control of viral replication (9).

Discontinuation of therapy usually results in rapid viral rebound to pretreatment viral load levels (12), although there have also been cases reported of virological control after treatment interruption $(21,35)$. The mechanisms responsible for this (temporary) virological control have thus far remained unclear. There is a debate about whether it is beneficial to start treatment during primary HIV-1 infection. Using computer simulations, Paci et al. showed that there is no difference in the disease-free period or survival after treatment interruption when HAART is started during the acute phase of primary infection, compared to starting it at a later stage during chronic infection (28). In contrast, Steingrover et al. did show a clinical benefit of starting HAART during primary infection, as they observed that the median time to viral rebound after treatment interruption was significantly longer in primary than in chronically-infected patients (33). Current guidelines, however, advise to start therapy in HIV-1-infected individuals when $\mathrm{CD}^{+}{ }^{+} \mathrm{T}$-lymphocyte counts (CD4 counts) drop below 350 cells $/ \mu \mathrm{L}$ (5). Between 1996 and 2000, according to the older guidelines, many HIV-1-positive individuals initiated HAART when CD4 counts were still above 350 cells $/ \mu \mathrm{L}$. Several of these individuals and their clinicians consider stopping HAART, often due to emerging toxicity or compliance

\footnotetext{
${ }^{1}$ Department of Immunology, and ${ }^{6}$ Department of Internal Medicine and Infectious Diseases, University Medical Center Utrecht, Utrecht, The Netherlands.

${ }^{2}$ Department of Internal Medicine, Division of Infectious Diseases, Tropical Medicine, and AIDS, Academic Medical Center, Amsterdam, The Netherlands.

${ }^{3}$ Department of Social Medicine, Academic Medical Center, Amsterdam, The Netherlands.

${ }^{4}$ Department of Infectious Diseases, Leiden University Medical Center, Leiden, The Netherlands.

${ }^{5}$ Department of Internal Medicine, Hospital Onze Lieve Vrouwe Gasthuis, Amsterdam, The Netherlands.
} 
problems. This interruption of therapy could result in the resolution of the adverse effects of HAART. The immunological consequences of treatment interruption are, however, not yet fully understood.

Here we present a detailed longitudinal analysis of both $\mathrm{CD}^{+}$and $\mathrm{CD} 8^{+} \mathrm{T}$-cell responses after treatment interruption in individuals who initiated HAART when their CD4 counts were still above 350 cells $/ \mu \mathrm{L}$. We compared different HIV-1specific T-cell functions in individuals who had a low viral load after treatment interruption with individuals who had higher viral load levels, to investigate a possible underlying immunological explanation for the difference between these two groups, who had at baseline comparable plasma viral loads.

\section{Materials and Methods}

\section{Patient characteristics}

A prospective, non-randomized, multicenter intervention study (TRIESTAN; Treatment Interruption in Early Starters Netherlands) was designed to evaluate the short-term and long-term outcome of HAART discontinuation among HIV1-infected individuals who initiated HAART with $\mathrm{CD}^{+}$ T-lymphocyte counts above 350 cells $/ \mu \mathrm{L}$ (31). The primary criteria for inclusion in the TRIESTAN study were: HIV-1positive, older than 18 years, initiation of HAART at a CD4 $4^{+}$ T-lymphocyte count above 350 cells $/ \mu \mathrm{L}$, no antiretroviral therapy prior to HAART, and at least $1 \mathrm{y}$ of HAART. In addition, at the time of inclusion, eligible individuals had to have an HIV-1 RNA load below 500 copies/mL, as well as a $\mathrm{CD}^{+}{ }^{+}$count of more than 500 cells $/ \mu \mathrm{L}$ for more than 6 mo (for other characteristics of the TRIESTAN study population see reference 31). All individuals who fulfilled the criteria for inclusion in this study were identified from the ATHENA national observational cohort, a collaboration of the $22 \mathrm{HIV}$ treatment centers in The Netherlands. Of the 46 individuals who decided to stop therapy, 11 individuals were selected for the present study based on viral load data, availability of cryopreserved PBMCs, and HLA type. They were subsequently followed for $24 \mathrm{wk}$ after treatment discontinuation. See Table 1 for treatment characteristics of the 11 individuals.

\section{Viral load determination}

Plasma HIV RNA load was quantified using the Quantiplex bDNA 3.0 assay (Bayer Corp., Tarrytown, NY), with a detection limit of 50 copies $/ \mathrm{mL}$.

\section{$C D 4^{+} T$-cell stimulation and intracellular cytokine staining}

Cryopreserved PBMCs were thawed and aliquotted at $2 \times 10^{6}$ cells per $\mathrm{mL}$ in round-bottom tubes (Becton Dickinson [BD], San Jose, CA). PBMCs were stimulated for $6 \mathrm{~h}$ with a Gag-peptide pool (15mers with 11 overlap, final concentration of the individual peptides was $2 \mu \mathrm{g} / \mathrm{mL}$; Consensus B, National Institutes of Health [NIH] AIDS Research and Reference Reagent Program, Bethesda, MD), in the presence of co-stimulation $(2 \mu \mathrm{g} / \mathrm{mL} \alpha \mathrm{CD} 28$; Sanquin Reagents, Amsterdam, The Netherlands), and $2 \mu \mathrm{g} / \mathrm{mL} \alpha \mathrm{CD} 49 \mathrm{~d}$ (Pharmingen, San José, CA). As a positive control, PMA and ionomycin $(5 \mathrm{ng} / \mathrm{mL}$ and $1 \mu \mathrm{g} / \mathrm{mL}$, respectively; SigmaAldrich, Zwijndrecht, The Netherlands) were used. After $1.5 \mathrm{~h}$, monensin ( $3 \mu \mathrm{M}$; Sigma-Aldrich) was added. After fixation and permeabilization (permeabilization reagents from $\mathrm{BD}$ ), the cells were stained with $\alpha \mathrm{CD} 3-\mathrm{PerCP}, \alpha \mathrm{CD} 4-$ PECy7, $\alpha$ IFN- $\gamma$-FITC, and $\alpha$ IL-2-PE monoclonal antibodies (BD) for $20 \mathrm{~min}$ at $4{ }^{\circ} \mathrm{C}$. The cells were fixed in cellfix (BD), and six-color flow cytometry was performed. The lymphocytes were gated based on forward- and sidewardscatter, and $\mathrm{CD}^{+} \mathrm{T}$ cells were gated on the basis of CD3 and CD4 expression. At least 300,000 events were acquired using the LSRII flow cytometer (BD). Responses above $0.02 \%$ after subtraction of negative control values were considered positive. Data were analyzed using DIVA software (BD).

\section{Tetramer staining and $C D 8^{+} T$-cell stimulation}

PBMCs were stimulated for $4 \mathrm{~h}$ with either the Gag peptide pool or a dominant HIV peptide (final concentration $1 \mu \mathrm{g} / \mathrm{mL})$, selected based on the individual's HLA type in the presence of monensin ( $3 \mu \mathrm{M}$; Sigma-Aldrich), and $\alpha \mathrm{CD} 107 \mathrm{a}-$

Table 1. Treatment Characteristics of the Study Subjects

\begin{tabular}{|c|c|c|c|c|c|}
\hline Subject & Group $^{a}$ & $\begin{array}{l}\text { Time to } \\
\text { HAART }^{\mathrm{b}}\end{array}$ & $\begin{array}{l}\text { Time on } \\
H A A R T^{\mathrm{c}}\end{array}$ & Treatment $^{\mathrm{d}}$ & $\begin{array}{l}\text { Ever failed } \\
\text { treatment }^{\mathrm{e}}\end{array}$ \\
\hline M19921 & I & 1 & 53 & $\mathrm{AZT}+3 \mathrm{TC}+\mathrm{LOP} / \mathrm{r}$ & No \\
\hline M17912 & I & 2 & 49 & $\mathrm{AZT}+3 \mathrm{TC}+\mathrm{NFV}$ & Yes \\
\hline M25638 & I & 2 & 78 & $3 \mathrm{TC}+\mathrm{TDF}+\mathrm{EFV}$ & No \\
\hline M11435 & I & 139 & 80 & $\mathrm{AZT}+3 \mathrm{TC}+\mathrm{NFV}$ & Yes \\
\hline M15769 & I & 41 & 79 & $\mathrm{AZT}+3 \mathrm{TC}+\mathrm{RTV}$ & Yes \\
\hline M28072 & II & 3 & 15 & $3 \mathrm{TC}+\mathrm{ABC}+\mathrm{TDF}$ & No \\
\hline M14770 & II & 5 & 79 & $\mathrm{~d} 4 \mathrm{~T}+3 \mathrm{TC}+\mathrm{NVP}$ & Yes \\
\hline M12953 & II & 31 & 75 & $\mathrm{AZT}+3 \mathrm{TC}+\mathrm{NVP}$ & Yes \\
\hline M26347 & II & 1 & 53 & $\mathrm{AZT}+3 \mathrm{TC}+\mathrm{NFV}$ & No \\
\hline M18173 & II & 19 & 46 & $\mathrm{AZT}+3 \mathrm{TC}+\mathrm{NVP}$ & No \\
\hline M13164 & II & 23 & 79 & $\mathrm{AZT}+3 \mathrm{TC}+\mathrm{EFV}$ & Yes \\
\hline
\end{tabular}

${ }^{\mathrm{a}}$ Group I had a high viral load, and group II had a low viral load.

${ }^{\mathrm{b}}$ Time between seroconversion and initiation of HAART in months.

${ }^{\mathrm{C}}$ Time on HAART in months.

${ }^{\mathrm{d}}$ Last treatment combination before HAART was interrupted.

${ }^{\mathrm{e}}$ Failed treatment once before HAART was interrupted.

3TC, lamivudine; d4T, stavudine; ABC, abacavir; RTV, ritonavir; NVP, nevirapine; LOP/r, lopinavir/ritonavir; TDF, tenofovir DF; NFV, nelfinavir; EFV, efavirenz. 


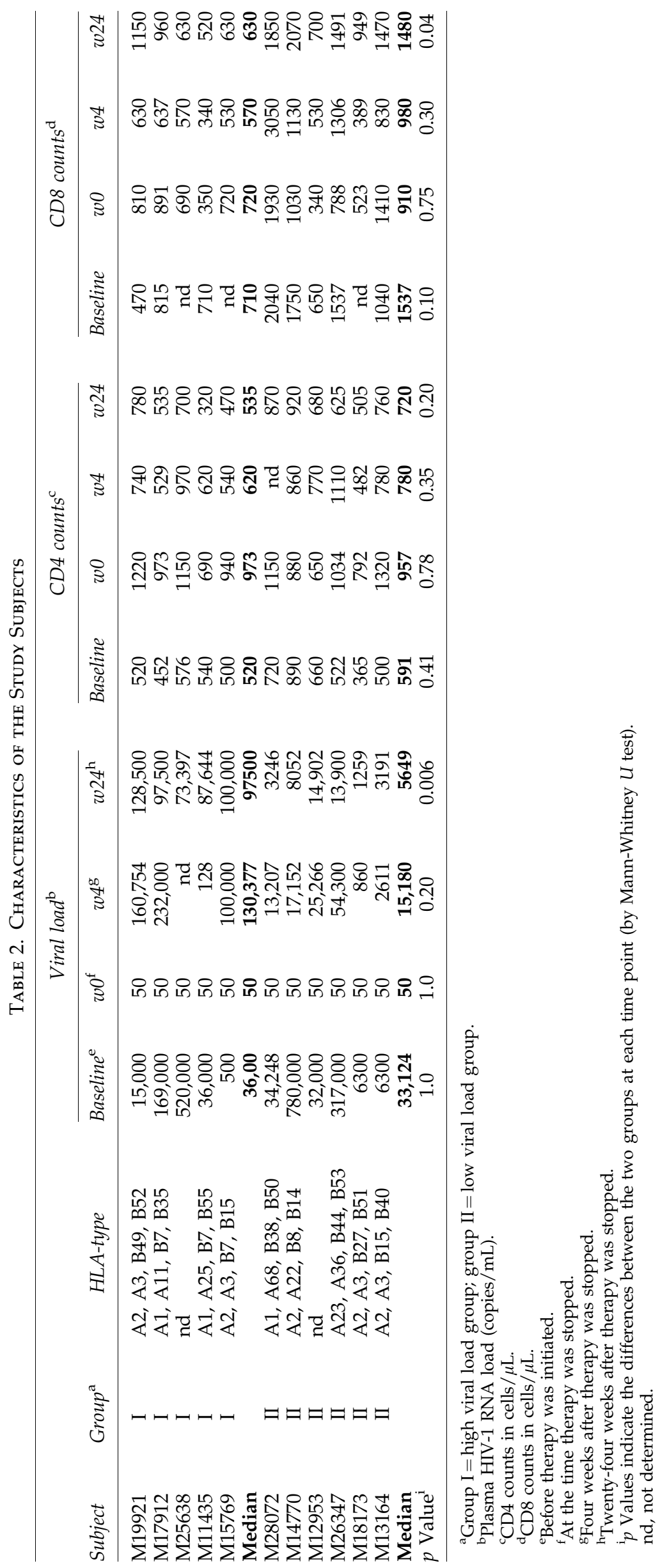


FITC (BD). The peptides used were HLA-A2 (SLYNTVATL)-, HLA-A3 (RLRPRGGKKK)-, HLA-B7 (TPGPGTRFP)-, or HLA-B8 (FLKEKKGL or EIYKRWII)-restricted.

Next the cells were stained with HIV-1-specific tetramers for $20 \mathrm{~min}$ at room temperature. Immunodominant peptides derived from HXB2 p17 Gag (SLYNTVATL) and Nef (TPGPGTRFP, FLKEKKGL) were tetramerized as previously described $(2,18)$, and used corresponding to the individual's HLA type. After fixation and permeabilization (permeabilization reagents from $\mathrm{BD}$ ), the cells were stained with $\alpha \mathrm{CD} 8$-PerCPCy5.5, $\alpha$ IFN- $\gamma$-PECy7, and $\alpha$ IL-2-APC monoclonal antibodies (BD) for $20 \mathrm{~min}$ at $4{ }^{\circ} \mathrm{C}$. The cells were fixed in cellfix (BD), and six-color flow cytometry was performed. The lymphocytes were gated based on forward- and sideward-scatter, and $\mathrm{CD} 8{ }^{+} \mathrm{T}$ cells were gated on the basis of CD3 and CD8 expression.

At least 300,000 events were acquired using the LSRII flow cytometer. Responses above $0.02 \%$ after subtraction of negative control values were considered positive. Data were analyzed using DIVA software.

\section{Flow cytometric analysis of T-cell activation markers}

Expression of activation markers on $\mathrm{CD}^{+}$and $\mathrm{CD}^{+} \mathrm{T}$ cells was measured after staining cells with $\alpha \mathrm{CD} 4-\mathrm{APC}$, $\alpha \mathrm{CD} 8$-PerCP, $\alpha$ CD38-FITC, and $\alpha$ HLA-DR-PE monoclonal antibodies (BD). All incubation steps were performed at $4{ }^{\circ} \mathrm{C}$ for $20 \mathrm{~min}$. Cells were fixed in cellfix and analyzed with the LSRII flow cytometer using DIVA software.

\section{Antigen-specific proliferation}

In vitro T-lymphocyte proliferation was measured using 5,6-carboxyfluorescein diacetate succinimidyl ester (CFSE; Molecular Probes, Leiden, The Netherlands), according to the manufacturer's protocol. Briefly, the PBMCs were thawed and the cells were labeled using CFSE for $8 \mathrm{~min}$ at room temperature. Labeling was stopped by using human pooled serum (HPS), and the cells were washed and aliquotted at $2 \times 10^{6}$ cells $/ \mathrm{mL}$ in round-bottom tubes. The cells were stimulated with the Gag peptide pool. As a positive control, $0.02 \mu \mathrm{g} \alpha \mathrm{CD} 3$ and $2 \mu \mathrm{g} \alpha \mathrm{CD} 28$ (Sanquin Reagents) was used. After $6 \mathrm{~d}$ of incubation at $37^{\circ} \mathrm{C}$ in $5 \% \mathrm{CO}_{2}$ the cells were stained using $\alpha \mathrm{CD} 3-\mathrm{PerCP}, \alpha \mathrm{CD} 4-\mathrm{PeCy} 7$, and $\alpha \mathrm{CD} 8$ $\mathrm{APC}$, as previously described. The percentage of $\mathrm{CD}^{+}$and $\mathrm{CD}^{+} \mathrm{T}$ cells that underwent one or more divisions was calculated by subtraction of the proliferation in the absence of the stimulus. Stimulation indices (SI) were calculated by dividing the percentage of proliferating cells after stimulation by the percentage proliferation of unstimulated cells.

\section{Statistical analysis}

Differences between patient groups were analyzed using the Mann-Whitney $U$ test. Wilcoxon tests were performed to determine differences between time points. Correlations were tested using Spearman's correlation test. All statistical analyses were performed using SPSS v. 12.01 (SPSS Inc., Chicago, IL).

\section{Results}

\section{Characteristics of the study population}

Eleven HIV-1-infected individuals with CD4 counts above 350 cells $/ \mu \mathrm{L}$ when treatment was initiated were included in this study. All individuals were successfully treated with HAART for at least 12 mo. At the time of therapy interruption, all individuals had an HIV-1 plasma RNA load below the detection limit of 50 copies/mL. After 24 weeks, however, the individuals could be divided in two groups based on their viral load. The first group (six individuals) was able to maintain a low viral load (viral load $<15,000$ copies $/ \mathrm{mL}$ ), whereas the second group (five individuals) was not (viral load >50,000 copies/mL; $p=0.006$; Table 2 and Fig. 1A). At baseline (before HAART was initiated), there was no significant difference between the two groups in viral load, or for CD4 and CD8 cell counts (Table 2).

\section{Treatment discontinuation results in an increase in activated $C D 8^{+} T$ cells}

Twenty-four weeks after cessation of therapy, the total CD8 cell counts were significantly higher in the individuals maintaining a low viral load $(p=0.04)$. Although the percentage of activated CD8 ${ }^{+} \mathrm{T}$ cells (as measured by the activation markers CD38 and HLA-DR) increased after treatment interruption in both groups, the percentage of activated $\mathrm{CD}^{+} \mathrm{T}$ cells at $24 \mathrm{wk}$ post-treatment discontinuation was significantly higher in those with a high viral load than in those with a low viral load (Fig. 1B; $p=0.011$ ). There was a clear correlation between the percentage of activated CD8 ${ }^{+} \mathrm{T}$ cells and viral load $(\mathrm{R}=0.791 ; p=0.004$ by Spearman's rho, data not shown) at $24 \mathrm{wk}$ after treatment interruption. Although there was also a slight increase in the percentage of activated $\mathrm{CD}^{+}{ }^{+} \mathrm{T}$ cells at $4 \mathrm{wk}$ after cessation of treatment, this did not reach significance, and the levels had decreased by $24 \mathrm{wk}$ post-cessation (data not shown).

\section{Stable number of cytokine-producing HIV-1-specific CD4 ${ }^{+} \mathrm{T}$ cells}

To determine whether the difference in viral load dynamics after treatment discontinuation could be explained by cytokine-producing $\mathrm{CD}^{+}{ }^{+} \mathrm{T}$ cells, both IFN- $\gamma$ and IL-2 production were analyzed after stimulation with an overlapping Gag-peptide pool. Levels of Gag-specific CD4 ${ }^{+} \mathrm{T}$ cells producing IFN- $\gamma$ or IL-2 were low but detectable during HAART in most individuals. After treatment interruption, both the percentages and absolute numbers of Gag-specific cytokineproducing $\mathrm{CD}^{+} \mathrm{T}$ cells remained comparable to the levels observed at the moment of treatment interruption (see Fig. $2 \mathrm{~A}$ for a representative example). No significant differences were observed between the two groups in either the percentage or the absolute number of cytokine producing $\mathrm{CD}^{+}$ T cells (Fig. 2B).

\section{Increased numbers of HIV-1-specific CD8 ${ }^{+} T$ cells after treatment discontinuation}

In the individuals expressing an HLA type for which tetramers were available, PBMCs were stained with one or more HIV-1-specific tetramers. In the total study population there was a significant increase in both the percentage [median (range) at week 0: $0.04 \%(0.03-0.11 \%)$, at week $24: 0.26 \%$ $(0-1.29 \%) ; p=0.043$ ], and the absolute number [week 0: 44 (14-143) tetramer ${ }^{+}$cells/mL, at week 24: 601 (47-1191) tetramer ${ }^{+}$cells $/ \mathrm{mL} ; p=0.028$ ] of HIV-1-specific $\mathrm{CD}^{+} \mathrm{T}$ cells after treatment interruption (Fig. 3A). There was a trend 

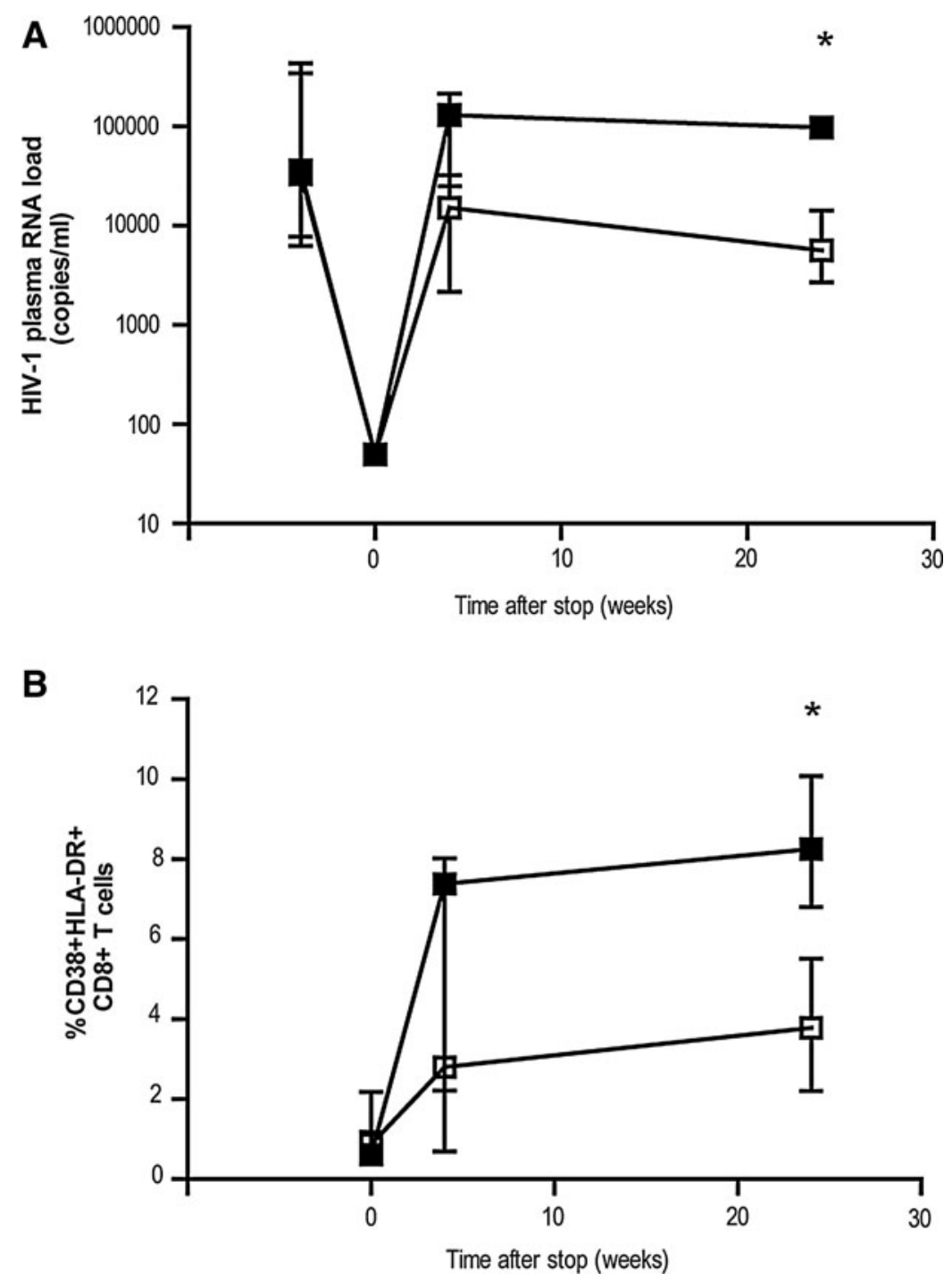

FIG. 1. Effect of treatment interruption on viral load and activation status of CD8 ${ }^{+} \mathrm{T}$ cells. Longitudinal analysis of HIV-1 RNA plasma viral load (A), and activated (HLA-DR and CD38 double-positive) $\mathrm{CD}^{+} \mathrm{T}$ cells (B), of individuals able to maintain a low viral load after cessation of therapy (open squares), and individuals who showed a rapid increase in viral load (solid squares; ${ }^{*} p<0.05$ ). For each time point the median value per group along with the interquartile range are shown.

toward higher percentages (and absolute numbers) of HIV-1specific $\mathrm{CD}^{+} \mathrm{T}$ cells in the individuals with a low viral load [week 0: $0.07 \%(0.04-0.11 \%)$, at week $24: 0.41 \%(0-0.58 \%)$ ], compared to those with a viral load $>50,000$ copies $/ \mathrm{mL}$ [week 0: 0.04\% (0.03-0.09\%), at week 24: 0.09\% (0.05-1.29\%)], but this difference was not significant.

\section{Higher numbers of functional $C D 8^{+} T$ cells are seen in individuals capable of maintaining a low viral load}

Recently, Lopez et al. have shown an increase in CD8 ${ }^{+}$ T-cell function at 12 mo after treatment interruption (22). This suggests that higher functionality of $\mathrm{CD}^{+} \mathrm{T}$-cell responses does not appear to be a consequence of a low level of virus replication. To reveal potential differences in $\mathrm{CD}^{+} \mathrm{T}$ cell function between individuals with low and high viral loads after treatment interruption, both cytokine production
(IFN- $\gamma$ and IL-2), as well as degranulation capacity (CD107a), were measured after stimulation with an overlapping Gag peptide pool, or selected optimal HLA class I HIV-1 peptides (see Fig. 3B for a representative example). Although the numbers of cytokine-producing $\mathrm{CD}^{+} \mathrm{T}$ cells remained low during follow-up, the number of CD107a-expressing CD8 ${ }^{+} \mathrm{T}$ cells in the total study population increased in the first $24 \mathrm{wk}$ after therapy interruption ( $p=0.05$; Fig. $3 C$ ). By comparing the total numbers of functional $\mathrm{CD}^{+} \mathrm{T}$ cells (i.e., the combination of IFN $-\gamma^{+}, \mathrm{IL}_{-} 2^{+}$, and $\mathrm{CD} 107 \mathrm{a}^{+} \mathrm{CD} 8^{+} \mathrm{T}$ cells), we observed a gradual increase after treatment interruption in the entire study population (Fig. 3D). Regression analysis showed that there was a significant relationship between the $\mathrm{CD}^{+} \mathrm{T}$-cell response at the time of treatment interruption and viral load at $24 \mathrm{wk}$ after treatment interruption in the entire study population $\left(R^{2}=0.47, p=0.028\right)$. The absolute numbers of functional $\mathrm{CD}^{+} \mathrm{T}$ cells at $4 \mathrm{wk}$ after cessation 
A
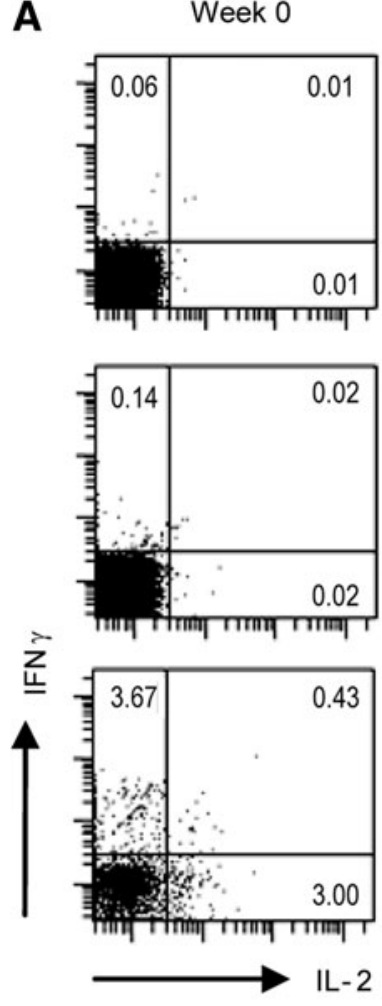

Week 4
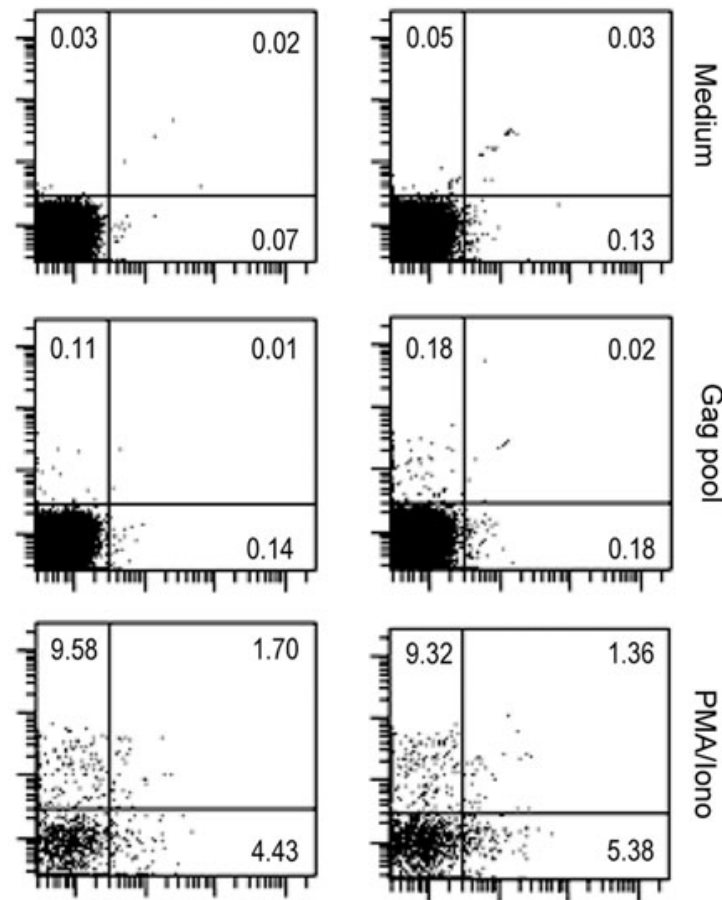

B

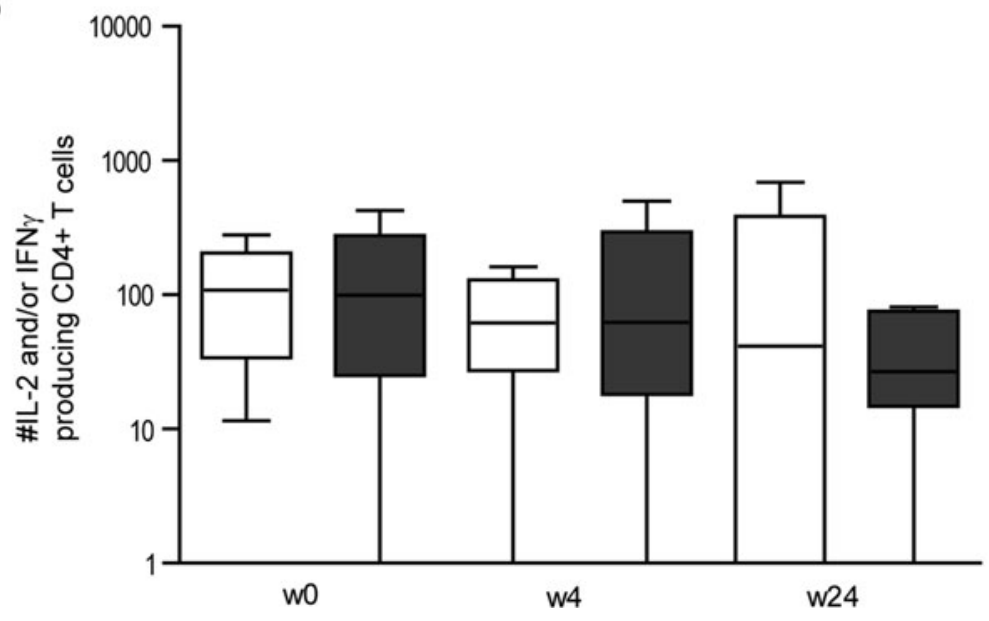

FIG. 2. Stable numbers of cytokine-producing HIV-1-specific CD4 ${ }^{+}$T cells. (A) Representative FACS examples of IFN- $\gamma$ and IL-2 production in $\mathrm{CD}^{+}{ }^{+} \mathrm{T}$ cells are shown after stimulation with medium, Gag-peptide pool (Gag pool), or PMA/ionomicine (PMA/Iono), at the time of therapy interruption (week 0), and 4 and 24 wk thereafter. The percentages of positive cells are indicated. (B) The total number of functional CD4 ${ }^{+} \mathrm{T}$ cells is shown (cells capable of producing IFN- $\gamma$ and/or IL-2). Within each box, the median is indicated by a horizontal line, the bars represent the $25-75 \%$ interval, and the whiskers represent the minimal and maximal values. The open boxes represent individuals with a viral load $<15,000$ copies $/ \mathrm{mL}$ at $24 \mathrm{wk}$ after treatment interruption, and the dark boxes represent individuals with a viral load $>50,000$ copies/mL at the same time point.

was significantly higher in individuals capable of maintaining a low viral load at $24 \mathrm{wk}$ after treatment interruption ( $p=0.043)$. Interestingly, albeit not significantly, when CD $4^{+}$ and $\mathrm{CD}^{+} \mathrm{T}$ cell numbers were combined, there appeared to already be a trend toward higher absolute numbers of functional $\mathrm{T}$ cells at the time of treatment interruption in individuals capable of maintaining a low viral load at $24 \mathrm{wk}$ after treatment was stopped (week $0, p=0.068$; Fig. 3E).

\section{No difference was seen in proliferative capacity of $C D 4^{+}$and $C D 8^{+} T$ cells}

Previously it has been shown that the capacity of HIV-1specific $\mathrm{CD}^{+} \mathrm{T}$ cells to proliferate upon stimulation with HIV-1 Gag correlated significantly with a persistently AIDSfree infection (32). Moreover, we have found that the proliferative capacity increases when individuals are treated 


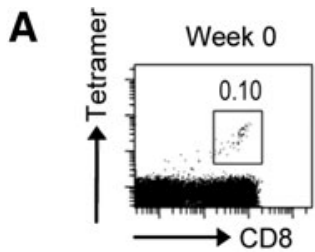

B
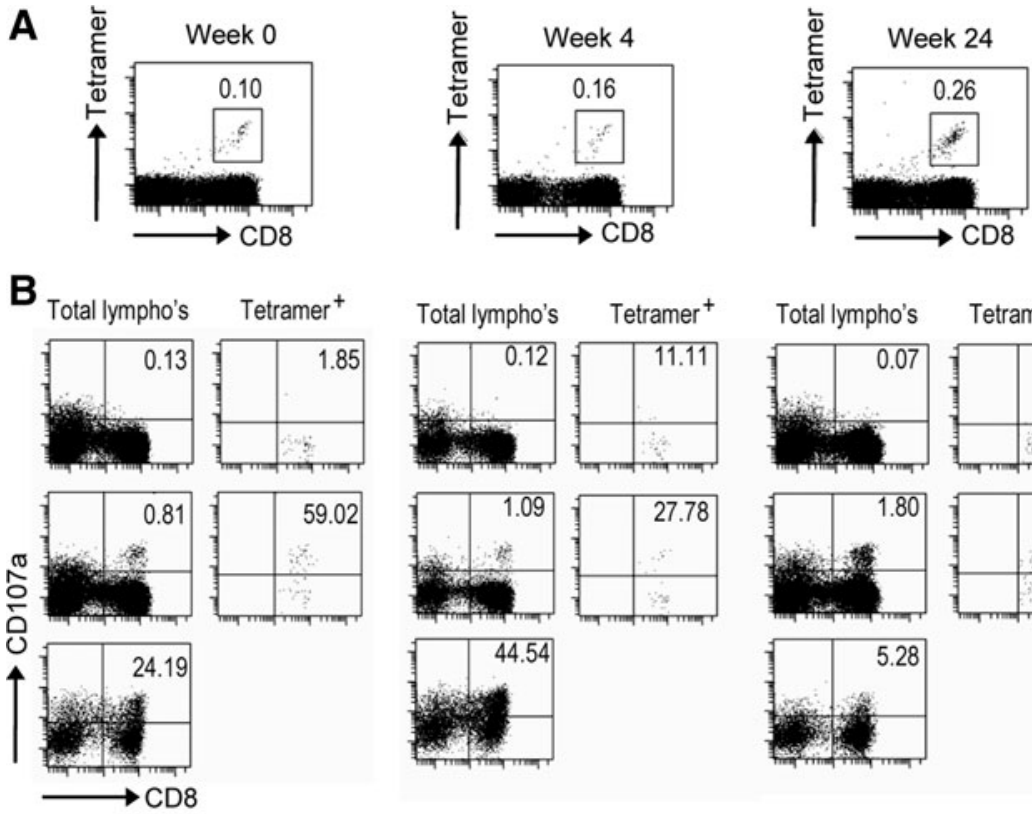

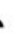
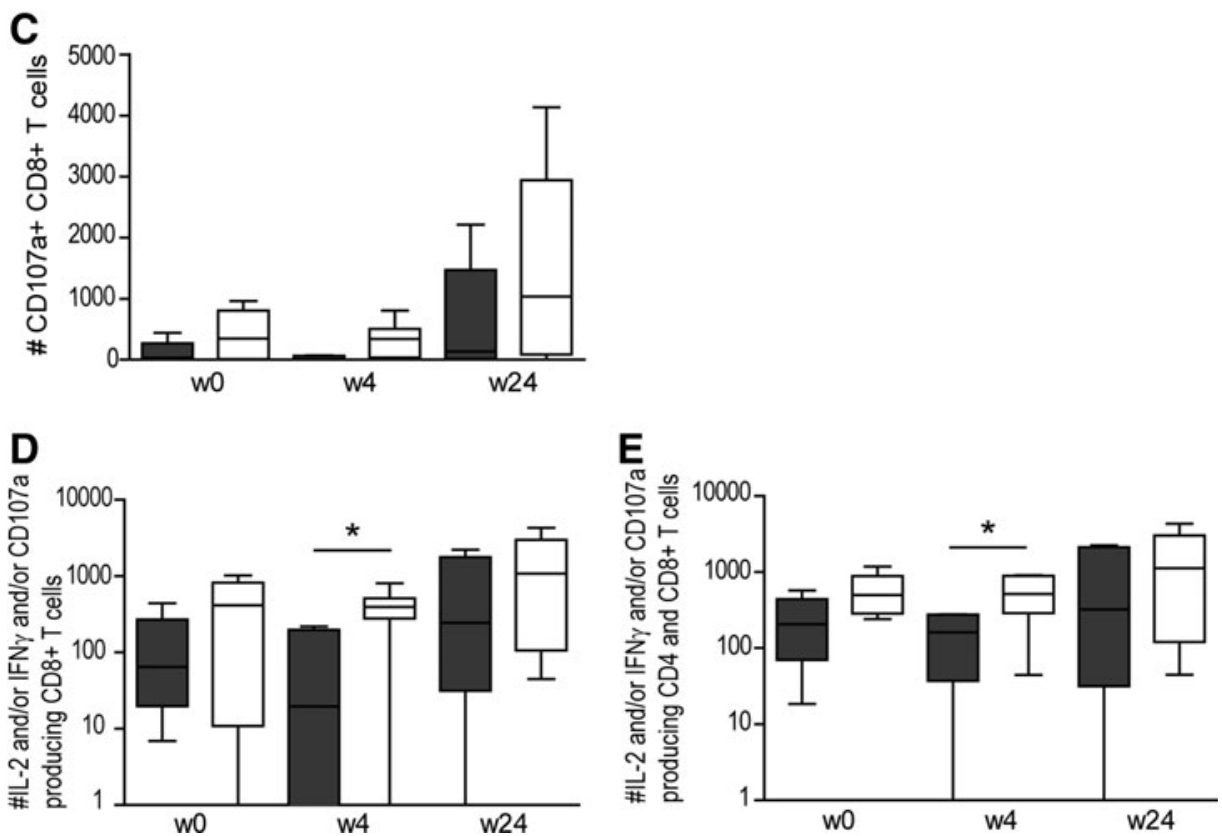

FIG. 3. Increased CD8 $8^{+}$-cell function in individuals capable of maintaining a low viral load. (A) Representative examples of tetramer staining are shown at the time of therapy interruption (week 0), and 4 and 24 wk thereafter. (B) Representative examples of staining for CD107a are shown in total lymphocytes, and tetramer-positive $\mathrm{T}$ cells, after stimulation with medium, Gag peptide pool (Gag pool), or PMA/ionomicine (PMA/Iono) for the same three time points. Percentages of positive cells are indicated in the upper right quadrant. (C) Shown here are the absolute numbers of CD107a-expressing $\mathrm{CD} 8^{+} \mathrm{T}$ cells. (D) Shown here are the total numbers of functional $\mathrm{CD} 8^{+} \mathrm{T}$ cells (i.e., cells capable of producing the cytokines IFN- $\gamma$, and/or IL-2, and/or CD107a). Within each box the median is indicated by a horizontal line, the bars represent the 25$75 \%$ interval, and whiskers represent the minimal and maximal values. Open boxes represent individuals with a viral load $<15,000$ copies $/ \mathrm{mL}$, while dark boxes represent individuals with a viral load $>50,000$ copies $/ \mathrm{mL}$ at $24 \mathrm{wk}$ after treatment interruption. (E) The total number of functional $\mathrm{T}$ cells (i.e., $\mathrm{CD} 4^{+}$and $\mathrm{CD} 8^{+} \mathrm{T}$ cells) is shown. Within each box the median is indicated by a horizontal line, the bars represent the $25-75 \%$ interval, and whiskers represent the minimal and maximal values. Open boxes represent individuals with a viral load $<15,000$ copies $/ \mathrm{mL}$, while dark boxes represent individuals with a viral load $>50,000$ copies $/ \mathrm{mL}$ at $24 \mathrm{wk}$ after treatment interruption.

with HAART, but decreases again when treatment is stopped (14). To investigate the proliferative capacity of HIV-1specific $\mathrm{T}$ cells after treatment interruption in the individuals studied here, CFSE dilution by cell proliferation after 6 days of stimulation with the overlapping Gag-peptide pool was studied. We used the combination of $\alpha \mathrm{CD} 3$ and $\alpha \mathrm{CD} 28$ as a positive control, which resulted in a mean SI of 21.27 (range 1.12-67.47). No significant difference in proliferative capacity 


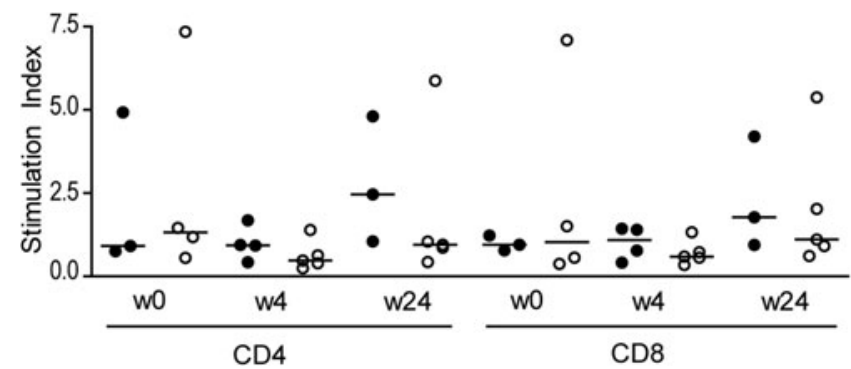

FIG. 4. No difference in the proliferative capacity of $\mathrm{CD} 4^{+}$ and $\mathrm{CD}^{+} \mathrm{T}$ cells was seen. PBMCs were labeled with CFSE and proliferative capacity was determined $6 \mathrm{~d}$ later. Stimulation indices for $\mathrm{CD} 4^{+}$and $\mathrm{CD} 8^{+} \mathrm{T}$ cells were calculated by dividing the percentage proliferation after stimulation with the Gag peptide pool by the percentage proliferation of unstimulated cells. Open circles represent individuals with a viral load $<15,000$ copies $/ \mathrm{mL}$, while dark circles represent individuals with a viral load $>50,000$ copies $/ \mathrm{mL}$ at $24 \mathrm{wk}$ after treatment interruption.

after stimulation with the Gag-peptide pool (Fig. 4), or positive control, was observed between the two groups for $\mathrm{CD}^{+} \mathrm{T}$ cells and $\mathrm{CD} 8^{+} \mathrm{T}$ cells, at any time point.

\section{Discussion}

Under previous guidelines in the late 1990s many HIV-1infected individuals started antiviral treatment when CD4 counts reached 350 cells $/ \mu \mathrm{L}$. Although some treatment interruption trials have shown an increase in disease progression $(7,8)$, treatment interruption with high CD4 counts has in principle been shown to be safe $(19,31)$. Here we describe a comprehensive study of 11 patients who initiated HAART with CD4 counts above 350 cells / $\mu \mathrm{L}$, and subsequently decided to stop treatment. These individuals could be divided into two groups: one with a viral load of $<15,000$ copies $/ \mathrm{mL}$ at $24 \mathrm{wk}$ after treatment cessation $(n=6)$, and a group with a viral load of $>50,000$ copies $/ \mathrm{mL}$ at 24 wk after treatment cessation $(n=5)$. Before HAART was initiated, the viral loads in the two groups were comparable. Here we examined immunological explanations for the observed differences in virologic control between these two groups.

During the 24 wk of follow-up after treatment interruption, the viral load in most individuals did not yet return to pretreatment levels (Table 2), as has been previously described (23). In most individuals, the viral load at $24 \mathrm{wk}$ after treatment discontinuation was still lower compared to pretreatment levels. Although the levels were significantly different at the end of the follow-up period, the kinetics of the changes in viral load after treatment interruption followed a similar trend in the two groups studied (Fig. 1A).

After treatment interruption, the number of activated $\mathrm{CD}^{+} \mathrm{T}$ cells, as well as the number of HIV-1-specific $\mathrm{CD} 8^{+} \mathrm{T}$ cells, increased in both groups. Emu et al. (9) have recently shown that control of HIV replication is associated with low levels of T-cell activation. In accord with these findings, we found that the increase in activated $\mathrm{CD}^{+} \mathrm{T}$ cells was significantly higher in the individuals with a viral load $>50,000$ copies/mL at $24 \mathrm{wk}$ after cessation than in individuals who maintained a low viral load. The latter individuals showed a more pronounced increase in the number of HIV-1-specific
$\mathrm{CD}^{+} \mathrm{T}$ cells as measured by tetramer staining. Due to the small number of individuals for whom tetramers were available (only two individuals in the high-load group and three individuals in the low-load group had an appropriate HLA type), this difference was not significant.

It has been previously shown that prolonged antiretroviral treatment is able to (at least partially) replenish the supply of IL-2-producing HIV-1-specific CD4 ${ }^{+} \mathrm{T}$ cells (11). There was, however, no difference between the two groups studied here in the percentages or the absolute numbers of antigenspecific $\mathrm{CD}^{+}{ }^{+} \mathrm{T}$ cells capable of producing IFN- $\gamma$ and/or IL-2 after stimulation with the overlapping Gag-peptide pool. In agreement with Iyasere et al. (13), and Zimmerli et al. (37), who found that during viremia the reduced in vitro proliferation of HIV-1-specific CD4 ${ }^{+} \mathrm{T}$ cells and CD8 ${ }^{+} \mathrm{T}$ cells was related to diminished IL-2 production, proliferative capacity was also low in the individuals studied here. Despite differences in viral rebound, no differences in proliferative capacity were observed between the two groups. Recently, Younes et al. (36) showed that the duration of antigen exposure may play a role in the ability of HIV-1-specific memory $\mathrm{CD}^{+} \mathrm{T}$ cells to proliferate upon stimulation with HIV-1-derived peptides. They reported that individuals who started antiretroviral treatment between 3 and 18 mo after HIV-1 infection had a higher proliferative capacity (as measured after 1 y of successful treatment), compared to individuals starting treatment 1 mo before or more than 3 y after HIV-1 infection. In agreement with these results, the two individuals with the highest proliferative responses in our study initiated HAART at 2 and 3 mo after seroconversion.

Degranulation is one of the main pathways by which cytotoxic $\mathrm{CD}^{+} \mathrm{T}$ cells can kill infected target cells (34). The numbers of $\mathrm{CD}^{+} \mathrm{T}$ cells expressing the degranulation marker CD107a after stimulation was higher than the numbers of IFN- $\gamma$ - and/or IL-2-producing $\mathrm{CD}^{+} \mathrm{T}$ cells in the same individuals, indicating that degranulation may be a more sensitive marker to study HIV-1-specific $\mathrm{CD}^{+} \mathrm{T}$-cell

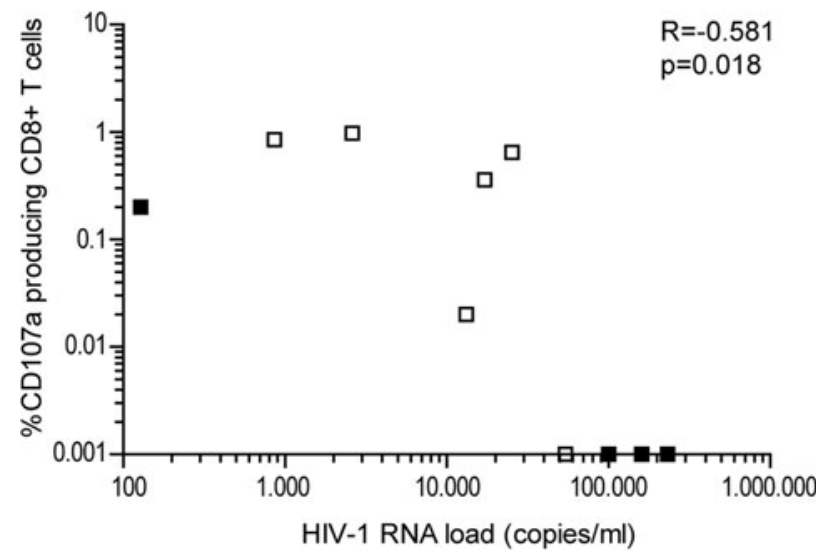

FIG. 5. Correlation between degranulation and viremia after treatment interruption. Four weeks after treatment interruption, a negative correlation was seen between degranulation (as measured by CD107a expression) and HIV-1 viral load. Individuals capable of maintaining low viral load are represented by open squares, and individuals who showed a high viral load at 24 wk after cessation of therapy are represented by black squares. 
activity than cytokine production. In agreement with this theory, Betts et al. (4) showed that CD107 expression can be measured at 10- to 100-fold lower peptide concentrations than those required for detectable cytokine production. Four weeks after treatment was discontinued, a negative correlation between degranulation and viremia could be observed $(\mathrm{R}=-0.581, p=0.018$ by Spearman's rho; Fig. 5$)$. These results suggest that there is a relationship between HIV-1 plasma RNA load and CD8 ${ }^{+} \mathrm{T}$-cell function, as measured by CD107a expression, after treatment discontinuation. We hypothesize that in individuals capable of maintaining low viral loads after treatment interruption, there is a modest increase in HIV antigen levels, which results in a boost of HIV-1-specific CD ${ }^{+}$T cells, leading to increased function. In individuals with high viral loads after treatment interruption, however, the large increase in antigen results in overactivation and thereby impairment of HIV-1-specific CD8 ${ }^{+} \mathrm{T}$ cells, leading to a less pronounced increase in their function.

Although treatment interruption in individuals who started HAART with CD4 counts above 350 cells / $\mu \mathrm{L}$ appears to be safe $(19,31)$, there is no evidence that the increase in HIV1-specific T-cell function seen after treatment interruption is more pronounced compared to individuals who started treatment during acute infection (14-16), or those with CD4 counts $<200$ cells $/ \mu \mathrm{L}(20,27)$. In these previous studies, the capacity of HIV-1-specific CD8 ${ }^{+} \mathrm{T}$ cells to degranulate after treatment interruption was not determined. As degranulation appears to be a more sensitive marker for the study of HIV-1-specific CD8 ${ }^{+}$T-cell functionality, it remains to be determined if the potential increase in CD107a expression seen after treatment interruption in individuals treated during acute infection, or those with low CD4 counts, is comparable to the increase seen in the individuals described here.

In conclusion, our data show that individuals capable of maintaining a low viral load after treatment discontinuation have increased $\mathrm{CD}^{+} \mathrm{T}$-cell function at $4 \mathrm{wk}$ after treatment cessation, compared to those who experienced a rapid increase in viral load. However, whether this increased function is a cause or a consequence of the low viral load in this group remains to be elucidated.

\section{Acknowledgements}

This work was financially supported by a grant from the Landsteiner Foundation for Blood Transfusion Research (LSBR grant no. 0317). The Gag-derived overlapping peptide pool (15-mers with 11 overlap, Consensus B) was obtained through the NIH AIDS Research and Reference Reagent Program, a division of the National Institute of Allergy and Infectious Diseases.

\section{Author Disclosure Statement}

No competing financial interests exist.

\section{References}

1. Alexander TH, Ortiz GM, Wellons MF, et al: Changes in CD4+ T-cell differentiation phenotype during structured treatment interruption in patients with chronic HIV-1 infection. J Acquir Immune Defic Syndr 2003;34:475-481.
2. Altman JD, Moss PA, Goulder PJ, et al.: Phenotypic analysis of antigen-specific T lymphocytes. Science 1996;274: 94-96.

3. Autran B, Carcelain G, Li TS, et al.: Positive effects of combined antiretroviral therapy on $\mathrm{CD} 4+\mathrm{T}$ cell homeostasis and function in advanced HIV disease. Science 1997;277: 112-116.

4. Betts MR, Price DA, Brenchley JM, et al.: The functional profile of primary human antiviral CD8 $+\mathrm{T}$ cell effector activity is dictated by cognate peptide concentration. J Immunol 2004;172:6407-6417.

5. Borleffs JC, Danner SA, Lange JM, and van Everdingen JJ: [CBO guidelines 'Antiretroviral therapy in the Netherlands']. Ned Tijdschr Geneeskd 2001;145:1585-1589.

6. Casazza JP, Betts MR, Picker LJ, and Koup RA: Decay kinetics of human immunodeficiency virus-specific CD8 $+\mathrm{T}$ cells in peripheral blood after initiation of highly active antiretroviral therapy. J Virol 2001;75:6508-6516.

7. Danel C, Moh R, Minga A, et al.: CD4-guided structured antiretroviral treatment interruption strategy in HIVinfected adults in west Africa (Trivacan ANRS 1269 trial): a randomised trial. Lancet 2006;367:1981-1989.

8. El-Sadr WM, Lundgren JD, Neaton JD, et al.: CD4+ countguided interruption of antiretroviral treatment. N Engl J Med 2006;355:2283-2296.

9. Emu B, Sinclair E, Favre D, et al.: Phenotypic, functional, and kinetic parameters associated with apparent T-cell control of human immunodeficiency virus replication in individuals with and without antiretroviral treatment. J Virol 2005;79: 14169-14178.

10. Gray CM, Lawrence J, Schapiro JM, et al.: Frequency of class I HLA-restricted anti-HIV CD8 + T cells in individuals receiving highly active antiretroviral therapy (HAART). J Immunol 1999;162:1780-1788.

11. Harari A, Petitpierre S, Vallelian F, and Pantaleo G: Skewed representation of functionally distinct populations of virusspecific CD4 T cells in HIV-1-infected subjects with progressive disease: changes after antiretroviral therapy. Blood 2004;103:966-972.

12. Hatano H, Vogel S, Yoder C, Metcalf JA, Dewar R, Davey RT $\mathrm{Jr}$, and Polis MA: Pre-HAART HIV burden approximates post-HAART viral levels following interruption of therapy in patients with sustained viral suppression. AIDS 2000; 14:1357-1363.

13. Iyasere C, Tilton JC, Johnson AJ, et al.: Diminished proliferation of human immunodeficiency virus-specific CD4+ T cells is associated with diminished interleukin-2 (IL-2) production and is recovered by exogenous IL-2. J Virol 2003; 77:10900-10909.

14. Jansen CA, De Cuyper I, Steingrover R, et al.: Analysis of the effect of highly active antiretroviral therapy during acute HIV-1 infection on HIV-specific CD4 T cell functions. AIDS 2005;19:1145-1154.

15. Kaufmann DE, Lichterfeld M, Altfeld M, et al.: Limited durability of viral control following treated acute HIV infection. PLoS Med 2004;1:e36.

16. Kaufmann DE, and Walker BD: Treatment interruption to boost specific HIV immunity in acute infection. Curr Opin HIV AIDS 2007;2:21-25.

17. Kostense S, Otto SA, Knol GJ, et al.: Functional restoration of human immunodeficiency virus and Epstein-Barr virusspecific $\mathrm{CD} 8(+) \mathrm{T}$ cells during highly active antiretroviral therapy is associated with an increase in CD4(+) T cells. Eur J Immunol 2002;32:1080-1089. 
18. Kostense $S$, Vandenberghe $K$, Joling J, van Baarle D, Nanlohy N, Manting E, and Miedema F: Persistent numbers of tetramer $+\mathrm{CD} 8(+) \mathrm{T}$ cells, but loss of interferon-gamma+ HIV-specific $\mathrm{T}$ cells during progression to AIDS. Blood 2002;99:2505-2511.

19. Krolewiecki AJ, Zala C, Vanzulli C, et al:: Safe treatment interruptions in patients with nadir CD4 counts of more than 350 cells/microL: a randomized trial. J Acquir Immune Defic Syndr 2006;41:425-429.

20. Lange CG, Xu Z, Patterson BK, et al.: Proliferation responses to HIVp24 during antiretroviral therapy do not reflect improved immune phenotype or function. AIDS 2004;18:605613.

21. Lisziewicz J, Rosenberg E, Lieberman J, et al.: Control of HIV despite the discontinuation of antiretroviral therapy. N Engl J Med 1999;340:1683-1684.

22. Lopez M, Rallon N, Soriano V, et al.: HIV rebound after discontinuation of antiretroviral therapy increases and expands HIV-specific CD8+ responses but has no impact on its functionality. AIDS Res Hum Retroviruses 2008;24:11971201.

23. Neumann AU, Tubiana R, Calvez V, et al:: HIV-1 rebound during interruption of highly active antiretroviral therapy has no deleterious effect on reinitiated treatment. Comet Study Group. AIDS 1999;13:677-683.

24. Notermans DW, Jurriaans S, Foudraine NA, et al.: Decrease of HIV-1 RNA levels in lymphoid tissue and peripheral blood during treatment with ritonavir, lamivudine and zidovudine. Ritonavir/3TC/ZDV Study Group. AIDS 1998;12:167-173.

25. Ogg GS, Jin X, Bonhoeffer S, et al.: Quantitation of HIV-1specific cytotoxic $\mathrm{T}$ lymphocytes and plasma load of viral RNA. Science 1998;279:2103-2106.

26. Ogg GS, Kostense S, Klein MR, Jurriaans S, Hamann D, McMichael AJ, and Miedema F: Longitudinal phenotypic analysis of human immunodeficiency virus type 1-specific cytotoxic T lymphocytes: correlation with disease progression. J Virol 1999;73:9153-9160.

27. Oxenius A, Price DA, Gunthard HF, et al: Stimulation of HIV-specific cellular immunity by structured treatment interruption fails to enhance viral control in chronic HIV infection. Proc Natl Acad Sci USA 2002;99:13747-13752.

28. Paci P, Carello R, Bernaschi M, D'Offizi G, and Castiglione F: Immune control of HIV-1 infection after therapy interruption: immediate versus deferred antiretroviral therapy. BMC Infect Dis 2009;9:172.

29. Pakker NG, Notermans DW, de Boer RJ, et al.: Biphasic kinetics of peripheral blood $\mathrm{T}$ cells after triple combination therapy in HIV-1 infection: a composite of redistribution and proliferation. Nat Med 1998;4:208-214.

30. Pitcher CJ, Quittner C, Peterson DM, Connors M, Koup RA Maino VC, and Picker LJ: HIV-1-specific CD4+ T cells are detectable in most individuals with active HIV-1 infection, but decline with prolonged viral suppression. Nat Med 1999;5:518-525.

31. Pogany K, van Valkengoed IG, Prins JM, et al.: Effects of active treatment discontinuation in patients with a CD4+ T-cell nadir greater than 350 cells $/ \mathrm{mm}^{3}$ : 48 -week Treatment Interruption in Early Starters Netherlands Study (TRIESTAN). J Acquir Immune Defic Syndr 2007;44:395-400.

32. Pontesilli O, Carotenuto P, Kerkhof-Garde SR, et al.: Lymphoproliferative response to HIV type 1 p24 in long-term survivors of HIV type 1 infection is predictive of persistent AIDS-free infection. AIDS Res Hum Retroviruses 1999;15: 973-981.

33. Steingrover R, Pogany K, Fernandez GE, et al.: HIV-1 viral rebound dynamics after a single treatment interruption depends on time of initiation of highly active antiretroviral therapy. AIDS 2008;22:1583-1588.

34. Trapani JA, and Smyth MJ: Functional significance of the perforin/granzyme cell death pathway. Nat Rev Immunol 2002;2:735-747.

35. Vila J, Nugier F, Bargues G, Vallet T, Peyramond D, Hamedi-Sangsari F, and Seigneurin JM: Absence of viral rebound after treatment of HIV-infected patients with didanosine and hydroxycarbamide. Lancet 1997;350:635-636.

36. Younes SA, Trautmann L, Yassine-Diab B, et al:: The duration of exposure to HIV modulates the breadth and the magnitude of HIV-specific memory CD4 $+\mathrm{T}$ cells. J Immunol 2007;178:788-797.

37. Zimmerli SC, Harari A, Cellerai C, Vallelian F, Bart PA, and Pantaleo G: HIV-1-specific IFN-gamma/IL-2-secreting CD8 $\mathrm{T}$ cells support CD4-independent proliferation of HIV-1specific CD8 T cells. Proc Natl Acad Sci USA 2005;102:72397244 .

Address correspondence to:

Dr. Debbie van Baarle

Lundlaan 6

3584 EA Utrecht

The Netherlands

E-mail: d.vanbaarle@umcutrecht.nl

Received June 10, 2010; accepted August 10, 2010. 